\section{Expression of parafibromin in major renal cell tumors}

\author{
C. Cui, P. Lal, S. Master, Y. Ma, T. Baradet, \\ Z. Bing
}

Department of Pathology and Laboratory Medicine, Hospital of the University of Pennsylvania, Philadelphia, PA, USA

\begin{abstract}
Parafibromin, encoded by HRPT2 gene, is a recently identified tumor suppressor. Complete and partial loss of its expression have been observed in hyperparathyroidismjaw tumor (HPT-JT), parathyroid carcinoma, breast carcinoma, lung carcinoma, gastric and colorectal carcinoma. However, little has been known about its expression in renal tumors. In order to study the expression of parafibromin in a series of the 4 major renal cell tumors - clear cell renal cell carcinoma (ccRCC), papillary renal cell carcinoma (pRCC), chromophobe renal cell carcinoma (chRCC) and oncocytoma, one hundred thirty nine renal tumors including 61 ccRCCs, 37 pRCCs, 22 chRCCs and 19 oncocytomas were retrieved and used for the construction of renal tissue microarrays (TMAs). The expression of parafibromin was detected by immunohistochemical method on the constructed TMAs. Positive parafibromin stains are seen in 4 out of 61 ccRCCs (7\%), 7 out of 37 pRCCs (19\%), 12 out of 23 chRCCs (52\%) and all 19 oncocytomas (100\%). Parafibromin expression varies significantly $\left(\mathrm{P}<8.8 \times 10^{-16}\right)$ among the four major renal cell tumors and were correlated closely with tumor types. No correlation of parafibromin expression with tumor staging in ccRCCs, pRCCs and chRCCs, and Fuhrman nuclear grading in ccRCCs and pRCCs was seen. In summary, parafibromin expression was strongly correlated with tumor types, which may suggest that it plays a role in the tumorigenesis in renal cell tumors.
\end{abstract}

\section{Introduction}

Renal cell tumors are defined as the renal neoplasms arising from the renal tubules. They account for approximately $90 \%$ of renal tumors. Under the current WHO histological classification of renal cell tumors, more than ten subtypes have been described. Among them, there are four main tumors comprising $95 \%$ of the overall renal cell tumors: clear cell renal cell carcinoma (ccRCC, 75\%), papillary renal cell carcinoma (pRCC, 10\%), chromophobe renal cell carcinoma (chRCC, $5 \%$ ) and the benign entity - oncocytoma (5\%). ${ }^{1}$ In the past two decades, there has been an increased understanding of tumor biology of these tumors, particularly with the employment of genetic studies. Each tumor has been recognized to be associated with a specific type of genetic abnormality. For example, ccRCC often has $3 p$ deletion, the majority of pRCC tumors harbor trisomy 7 and 17, chRCC contains multiple monosomies, and the majority of oncocytomas show a normal chromosomal profile. $^{2}$ Molecular biomarkers are less well studied and further studies are needed to refine diagnoses, predict prognoses and provide bases for targeted therapies.

Hereditary HPT-JT syndrome is a rare autosomal dominant syndrome with an increased risk of parathyroid tumors, ossifying fibromas of the jaw and renal hamartomas and cystic kidney disease. ${ }^{3,4}$ Studies of this syndrome identified a link to HRPT2, and a germ line mutation in this gene was shown to be responsible for HPT-JT syndrome. ${ }^{5,6}$ HRPT2 germline mutations are also responsible for a subset of familial isolated hyperparathyroidism. ${ }^{7}$ HRPT2 gene encodes a protein called parafibromin, a $-60 \mathrm{KDa}$ protein composed of 531 amino acids and bearing sequence resemblance with the yeast protein Cdc73. ${ }^{8}$ Parafibromin is a member of the polymerase associated factor 1 (PAF1) complex that is involved in chromatin remodeling by histone ubiquitination and methylation, thereby regulating gene expression.9,10 Furthermore, it functions as a putative tumor suppressor and has been shown to provide multiple tumor suppressive functions by inducing apoptosis, inhibiting the G1 to $\mathrm{S}$ phase transition, and directly regulating growth factor gene expression by binding to their promoters. ${ }^{11-14}$ Normally, parafibromin is ubiquitously expressed in a variety of human tissues. ${ }^{15}$ Complete and partial loss of its expression have been observed in HPT-JT, parathyroid carcinoma, breast carcinoma, lung carcinoma, gastric and colorectal carcinoma. ${ }^{16-22}$ In addition, down-regulation of its expression has been found to be associated with aggressiveness of tumor behaviors and adverse prognosis of the above tumors. Nevertheless, little has been known about its role in renal tumors. In this study, we examined the expression of parafibromin in a series of the four major renal cell tumors using TMAs.
Correspondence: Dr. Zhanyong Bing, Department of Pathology and Laboratory Medicine, Hospital of the University of Pennsylvania, 3400 Spruce Street, Philadelphia, PA 19104, USA.

Tel. +1.215.662-6503 - Fax: +1.215.349-5910.

E-mail: bingz@uphs.upenn.edu

Key words: parafibromin, renal epithelial tumors.

Received for publication: 26 April 2012.

Accepted for publication: 29 June 2012.

This work is licensed under a Creative Commons Attribution NonCommercial 3.0 License (CC BYNC 3.0).

CC Copyright C. Cui et al., 2012

Licensee PAGEPress, Italy

European Journal of Histochemistry 2012; 56:e39 doi:10.4081/ejh.2012.e39

\section{Materials and Methods}

\section{Tissue microarray}

One hundred thirty nine renal cell tumors including 61 cases of ccRCC, 37 cases of pRCC, 22 cases of chRCC and 19 cases of oncocytoma from 1991 to 2009 were retrieved from the pathology archives of the Hospital of the University of Pennsylvania and used for the construction of renal TMAs. The study was approved by the institutional review board of the University of Pennsylvania. Renal TMAs were constructed using formalin fixed, paraffin embedded tissue using a tissue arrayer (Beecher Instruments, Silver Spring, MD, USA). Each block contains three representative $1.0 \mathrm{~mm}$ cores from the diagnostic areas of each case.

\section{Hemotoxylin and eosin stain}

Five $\mu \mathrm{m}$ sections were prepared from TMA blocks, and were deparaffinized, rehydrated and stained with hematoxylin and eosion for light microscopic examination.

\section{Immunohistochemistry}

Formalin-fixed and paraffin embedded tissues were sectioned and placed on plus-coated slides (Fisher Scientific, Pittsburgh, PA, USA) and dried overnight at $60^{\circ} \mathrm{C}$. Sections were de-waxed in xylene and rehydrated through graded ethanol to distilled water. Antigen retrieval was carried by the steam method in ethylenediaminetetraacetic acid (EDTA) buffer, pH 9.0 (DAK0, Glostrup, 
Denmark) for $30 \mathrm{~min}$ at $95^{\circ} \mathrm{C}$. Sections were then allowed to cool to room temperature and washed in DAKO Wash Buffer (DWB) (DAK0). Labeling was carried out using a mouse monoclonal anti-parafibromin antibody (\#SC-33678, Santa Cruz Biotech, Santa Cruz, CA, USA) at a dilution of 1:10 in DAKO Primary Antibody Diluent (DAKO) for $30 \mathrm{~min}$ at room temperature in a humidified chamber.

Following washing in DWB, the primary antibody was labeled with anti-mouse horseradish peroxidase (HRP) antibody (DAK0) for $30 \mathrm{~min}$ at room temperature in a humidified chamber. Following washing in DWB, the label was visualized with DAB (DAK0). The sections were then washed in distilled water, counterstained with hematoxylin, dehydrated, mounted (Cytoseal-60, Richard-Allan Scientific) and cover slipped. The normal renal cortex was used as positive control. The nuclear staining was classified into 3 patterns with modification to Gill et al. ${ }^{17}$ The positive case shows $>$ or $=75 \%$ of the epithelial nuclei. Less than $25 \%$ positive nuclear staining was defined as negative. All of others in between were considered intermediate.

\section{Statistical analysis}

All statistical calculations were performed using R 2.14.0 (www.r-project.org). Count data were analyzed using Fisher's exact test. The Bonferroni method was used to correct for multiple hypothesis testing. Estimates of error in the reported proportions were obtained using a Clopper-Pearson exact binomial test.

\section{Results}

In order to measure parafibromin expression in a cohort of renal cell tumors representing the four major subtypes, we constructed a tissue microarray containing 139 tumors. In our study, the small areas of tissue microarray of the enrolled cases revealed either positive or negative parafibromin staining. There is no intermediate staining seen. In the normal kidney we observed positive parafibromin staining in renal tubular cells and the mesangial cells of the glomeruli (Figure $1 \mathrm{~A}, \mathrm{~B}$ ), consistent with a previous report. ${ }^{15}$ The positive nuclei in renal tubules accounted for $75 \%$ or more of tubular nuclei (Figure 1 A,B). Sixty one of the tumors on our TMA had been classified as ccRCCs, and represented tumor sizes ranging from 1.4 to $15 \mathrm{~cm}$ with an average size of $5.4 \mathrm{~cm}$. Of these $61 \mathrm{ccRCCs}$, only 4 cases (7\%) were positive for parafibromin stain, while the remaining 57 were negative (Figure $2 \mathrm{~A}, \mathrm{~B}$ ). We arrayed $37 \mathrm{pRCCs}$, of which 15 were type $1 \mathrm{pRCCs}$ that ranged in size from
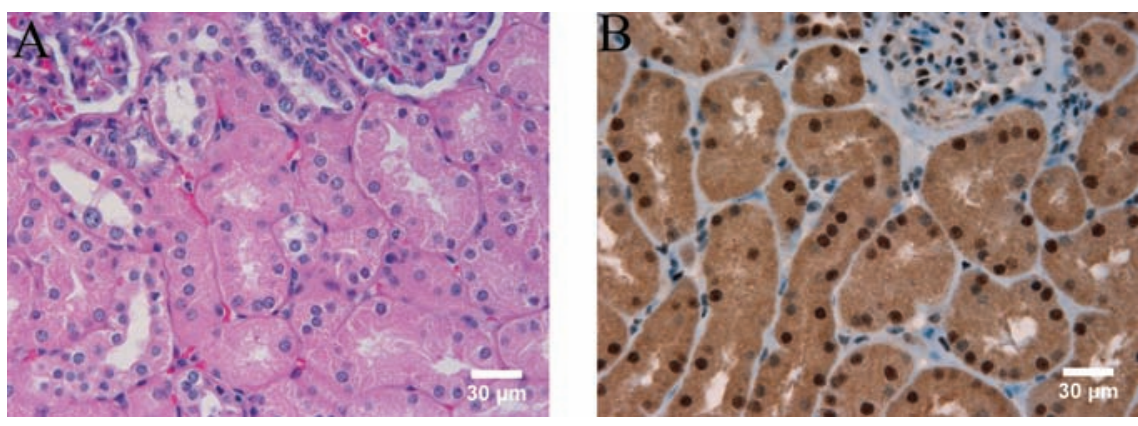

Figure 1. Immunohistochemical staining of parafibromin in normal kidney, $x$ 400. A) hematoxylin and eosin stain. B) parafibromin immunostaining.
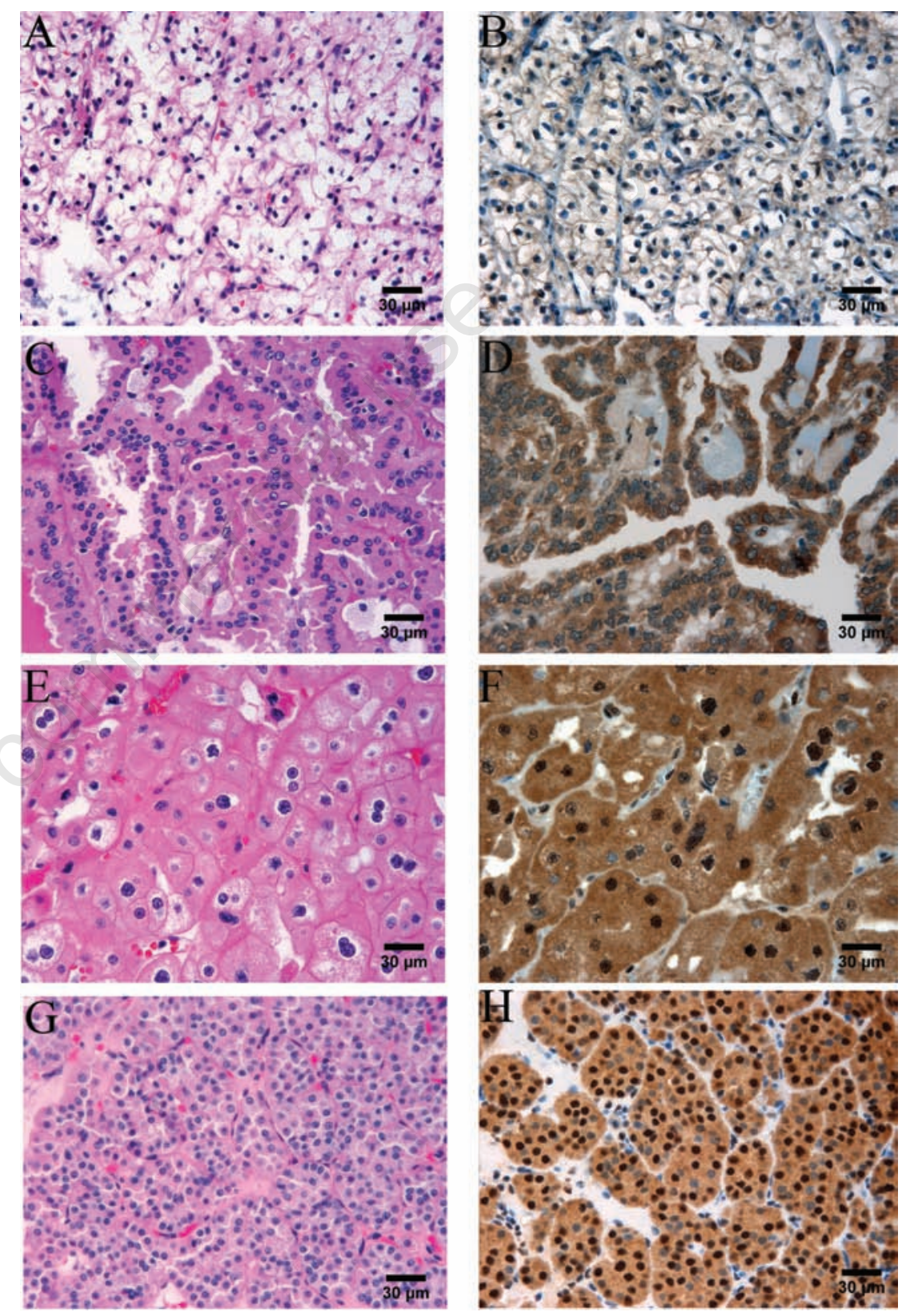

Figure 2. Parafibromin stain in major renal epithelial tumors, $x$ 400. A and B) ccRCC; parafibromin stain is negative in the tumor cells (B). C and D) pRCC; parafibromin stain is negative in the tumor cells (D). E and F) chRCC; there are diffusely and strongly parafibromin stains in the tumor cells (F). G and H) Oncocytoma; there are diffusely and strongly parafibromin stains in the tumor cells $(\mathrm{H})$. 
1.8 to $14.0 \mathrm{~cm}$ with an average of $4.1 \mathrm{~cm}$. One of these cases was positive for parafibromin stain, and the remaining 14 were negative. Twenty two cases were type 2 pRCCs, ranging in size from 0.9 to $14.0 \mathrm{~cm}$ with an average of $4.0 \mathrm{~cm}$. 6 of these were positive for parafibromin stain and 16 were negative (Figure 2 C,D). Overall, there were 7 parafibromin positive pRCCs (19\%). Twenty three chRCCs were arrayed, ranging in size from 1.3 to $20.0 \mathrm{~cm}$ with an average of $4.9 \mathrm{~cm}$. Twelve (52\%) showed strong positive staining (Figure 2 E,F) and 11 were negative. Finally, 19 oncocytoma cases were included, ranging in size from 1.1 to $4.8 \mathrm{~cm}$ with an average of $2.7 \mathrm{~cm}$. All of them (100\%) showed strong positive staining (Figure $2 \mathrm{G}, \mathrm{H}$ ). The distribution of cases with positive parafibromin stain varied significantly $\left(\mathrm{P}=8.8 \times 10^{-16}\right.$ by Fisher's exact test) among the four major renal cell tumors (Figure 3 ). Bonferroni corrected univariate comparisons showed strongly significant differences between ccRCC and chRCC as well as between oncocytoma and each of the other subtypes (Table 1). The overall percentage of positive cases within the subgroups ranged from $7 \%$ in ccRCC up to $100 \%$ in oncocytoma (Figure 3 ).

Pathologic tumor staging is the most important prognostic factor for renal cell tumors. Therefore we included the tumor staging of all 3 malignant renal cell tumors (ccRCC, pRCC and chRCC) in our study (Table 2). In the 4 parafibromin positive ccRCCs, 2 were pT1 tumors, one was pT2 and one was pT3; in the 57 parafibromin negative ccRCCs, 34 were pT1, 16 were pT2, 6 were pT3 and one was pT4. The only parafibromin positive type 1 pRCC was pT1 tumor; the 14 parafibromin negative type 1 pRCCs were: 12 pT1, one pT2 and one pT3. All 6 parafibromin positive type 2 pRCCs were pT1; the 16 negative type 2 pRCCs were: 11 pT1, 2 pT2 and 3 pT3. The 12 parafibromin positive chRCCs were all pT1 tumors; the 11 negatives were: 7 pT1, 2 pT2 and 2 pT3. Even though all the pRCC and chRCC cases with positive parafibromin stain were pT1 tumors, the 4 positive ccRCCs covered pT1, pT2 and pT3 tumors. After accounting for multiple hypothesis testing, these results were insufficient to establish an association of parafibromin expression with tumor staging in ccRCC, pRCC and chRCC.

Fuhrman nuclear grading is the second most important prognostic factor after tumor staging. In our study, we analyzed Fuhrman grading of ccRCCs and pRCCs concurrent with parafibromin staining (Table 3). The 4 parafibromin positive ccRCCs were: 2 grade II and 2 grade III; 57 negative cases were: 2 grade I, 40 grade II, 11 grade III and 4 grade IV. The only parafibromin positive type 1 pRCC was Fuhrman grade II; the 14 negatives were: 2 grade I and 12 grade II. The 6 parafibromin

\section{Percentage of parafibromin positive renal cell tumors within 4 major subtypes}

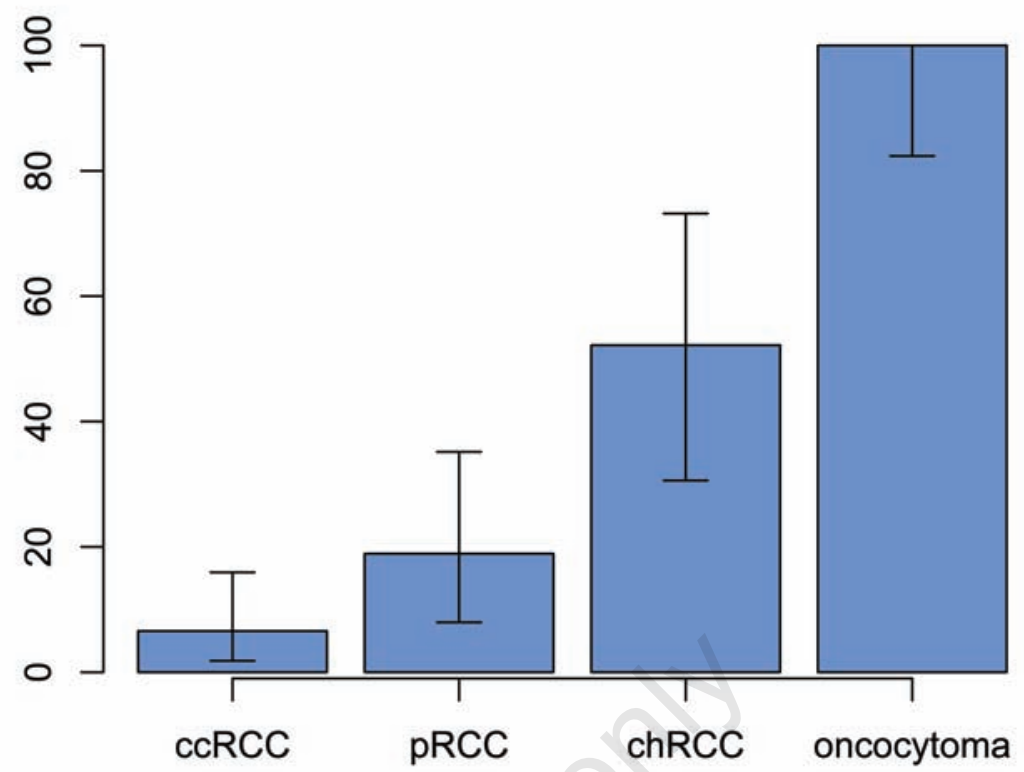

Figure 3. Percentage of parafibromin stain in four major renal cell tumors. Parafibromin expression varies significantly $\left(P<8.8 \times 10^{-16}\right)$ among the four major renal cell tumors. Percentages are shown along with $95 \%$ binomial confidence intervals

Table 1. Univariate pairwise comparisions between different classes of renal cell tumors.

\begin{tabular}{lccc} 
& pRCC & chRCC & Oncocytoma \\
ccRCC & 0.54 & $6.60 \mathrm{E}-05$ & $4.62 \mathrm{E}-14$ \\
pRCC & 0.06 & $1.50 \mathrm{E}-09$ \\
\hline chRCC & & $1.98 \mathrm{E}-03$ \\
\hline
\end{tabular}

pRCC, papillary renal cell carcinoma; chRCC, chromophobe renal cell carcinoma; ccRCC, clear cell renal cell carcinoma.

Table 2. Parafibromin expression and the American Joint Committee on Cancer's tumor staging of clear cell renal cell, papillary renal cell and chromophobe renal cell carcinomas.

\begin{tabular}{|c|c|c|c|c|c|c|c|}
\hline & \multicolumn{3}{|c|}{$\begin{array}{l}\text { Parafibromin positive } \\
\text { Tumor staging }\end{array}$} & \multicolumn{4}{|c|}{$\begin{array}{c}\text { Parafibromin negative } \\
\text { Tumor staging }\end{array}$} \\
\hline & I & II & III IV & I & II & III & IV \\
\hline ccRCC (total 61) & 2 & 1 & 1 & 34 & 16 & 6 & 1 \\
\hline $\begin{array}{l}\text { pRCC (total } 37) \\
\text { type I (15) } \\
\text { type II (22) }\end{array}$ & $\begin{array}{l}1 \\
6\end{array}$ & & & $\begin{array}{l}12 \\
11\end{array}$ & $\begin{array}{l}1 \\
2\end{array}$ & $\begin{array}{l}1 \\
3\end{array}$ & \\
\hline chRCC (total 23) & 12 & & & 7 & 2 & 2 & \\
\hline
\end{tabular}

ccRCC, clear cell renal cell carcinoma; pRCC, papillary renal cell carcinoma; chRCC, chromophobe renal cell carcinoma.

Table 3. Parafibromin expression and Fuhrman nuclear grading of clear cell renal cell carcinoma and papillary renal cell carcinoma.

\begin{tabular}{|c|c|c|c|c|c|c|}
\hline & $\begin{array}{l}\text { Parafibre } \\
\text { Fuhrman n }\end{array}$ & $\begin{array}{l}\text { positive } \\
\text { zar grading }\end{array}$ & & afi & $\begin{array}{l}\text { in ne } \\
\text { lear }\end{array}$ & $\begin{array}{l}\text { ive } \\
\text { ding }\end{array}$ \\
\hline & I II & III IV & I & II & III & IV \\
\hline ccRCC (total 61) & 2 & 2 & 2 & 40 & 11 & 4 \\
\hline pRCC (total 37) & & & & & & \\
\hline type I (15) & 1 & & 2 & 12 & & \\
\hline type II (22) & 2 & 4 & & 5 & 10 & 1 \\
\hline
\end{tabular}

ccRCC, clear cell renal cell carcinoma; pRCC, papillary renal cell carcinoma. 
positive type 2 pRCCs were: 2 grade II, 4 grade III; 16 negatives were: 5 grade II, 10 grade III and one grade IV. There was no statistically significant association of parafibromin expression with Fuhrman nuclear grading in ccRCC and pRCC identified in our study.

\section{Discussions}

Parafibromin is an oncosuppressor encoded by the hyperparathyroidism 2 (HRPT2) gene, which is located in human chromosome 1q31.2, consists of 17 exons and spans $18.5 \mathrm{~kb}$ in the genome. It encodes a 2.7-kb transcript which is translated into a 531-amino-acid parafibromin protein with a molecular weight of $60 \mathrm{kd}^{5,23}$ HRPT2 transcript has been shown to be expressed in heart, brain, placenta, lung, liver, skeletal muscle, kidney and pancreas. ${ }^{5}$ The 60 -kd protein has been shown in the adrenal gland, heart, pancreas and kidney. ${ }^{24}$ Immunohistochemical stain shows the higher expression of parafibromin in glomerular mesangial cell, hepatocytes, cells of the base of gastric glands, renal cortex tubules and the pars intermedia of the hypophysis. ${ }^{15}$

Parafibromin can function as a tumor suppressor. Parafibromin is a critical component of the RNA polymerase II-associated factor (PAF) complex which inhibits cyclin D1 and cmyc by recruiting the histone methyltransferase SUV39H1. ${ }^{8}$ Overexpression of parafibromin was shown to inhibit colony formation and cellular proliferation and induce cell cycle arrest in the G1 phase, indicating that parafibromin has a critical role in cell growth. ${ }^{14}$ Parafibromin expression was inversely linked to tumor size, pathologic stage and lymphovascular invasion of breast, ${ }^{18}$ colorectal ${ }^{22}$ and gastric ${ }^{21}$ carcinomas, and also may correlate with the prognosis in lung cancers. ${ }^{20}$

Parafibromin can function as an oncogene. Dephosphorylation of parafibromin by SHP2 makes it stably bind to beta-catenin and induce Wnt target genes and therefore cause tumor formation and progress. ${ }^{25}$

Parafibromin is expressed in renal tubules. ${ }^{5}$ In hyperparathyroidism-jaw tumor syndrome, there is increased occurrence in renal neoplasia. ${ }^{26-28}$ It has been shown that there are frequent allelic imbalances and novel mutations of the HRPT2 gene in sporadic human renal tumors. ${ }^{29}$ To further investigate the expression pattern of parafibromin in renal epithelial neoplasia, we constructed renal TMA to investigate the expression of this factor in major renal epithelial tumors. Morphologically and cytogenetically, ccRCC, pRCC, chRCC and oncocytoma have been recognized as distinctive subtypes of major renal cell tumors that have different prognosis. Our study showed that parafibromin expression varied significantly $\left(\mathrm{P}<8.8 \times 10^{-16}\right)$ among the four major renal cell tumor subtypes, with ccRCC has lowest positive rate, while oncocytoma is totally positive. Bonferroni corrected univariate comparisons showed strongly significant differences between ccRCC and chRCC as well as between oncocytoma and each of the other subtypes (Table 3). These results suggested that parafibromin might play a role in the tumorigenesis of renal epithelial neoplasia. The expression of parafibromin was previously investigated in a small number of chRCC $(\mathrm{n}=11)$ and oncocytoma $(\mathrm{n}=7)$, which showed negative stain in chRCC and positive staining in oncocytoma ${ }^{30}$ In our study, more cases of these two types of tumors were included. Our results were consistent with the previous finding in oncocytoma but with a higher positive rate than the previous report in chRCC.

In summary, our data indicated that the parafibromin expression was tightly correlated with the tumor types. Our study did not identify any association of parafibromin expression with tumor staging in ccRCC, pRCC and chRCC and Fuhrman nuclear grading in ccRCC and pRCC. The number of cases in this study was limited; a study with a much bigger sample size is needed to further explore the correlation between the expression of parafibromin and the stages and grades of renal epithelial tumors.

\section{References}

1. Eble JN, Sauter G, Epstein JI, Sesterhenn IA. World Health Organization classification of tumours. Pathology and genetics tumours of the urinary system and male genital organs. Lyon, France, IARC Press, 2004, pp 10.

2. Hagenkord JM, Gatalica Z, Jonasch E, Monzon FA. Clinical genomics of renal epithelial tumors. Cancer Genet 2011;204:285-97.

3. Tan MH, Teh BT. Renal neoplasia in the hyperparathyroidism-jaw tumor syndrome. Curr Mol Med 2004;4:895-7.

4. Teh BT, Farnebo F, Kristoffersson U, Sundelin B, Cardinal J, Axelson R, et al. Autosomal dominant primary hyperparathyroidism and jaw tumor syndrome associated with renal hamartomas and cystic kidney disease: linkage to 1q21-q32 and loss of the wild type allele in renal hamartomas. J Clin Endocrinol Metab 1996;81:4204-11.

5. Carpten JD, Robbins CM, Villablanca A, Forsberg L, Presciuttini S, Bailey-Wilson J, et al. HRPT2, encoding parafibromin, is mutated in hyperparathyroidism-jaw tumor syndrome. Nat Genet 2002;32:676-
80 .

6. Szabo J, Heath B, Hill VM, Jackson CE, Zarbo RJ, Mallette LE, et al. Hereditary hyperparathyroidism-jaw tumor syndrome: the endocrine tumor gene HRPT2 maps to chromosome 1q21-q31. Am J Hum Genet 1995;56:944-50.

7. Masi G, Barzon L, Iacobone M, Viel G, Porzionato A, Macchi V, et al. Clinical, genetic, and histopathologic investigation of CDC73-related familial hyperparathyroidism. Endocr Relat Cancer 2008; 15:1115-26.

8. Newey PJ, Bowl MR, Thakker RV. Parafibromin--functional insights. J Intern Med 2009;266:84-98.

9. Chaudhary K, Deb S, Moniaux N, Ponnusamy MP, Batra SK. Human RNA polymerase II-associated factor complex: dysregulation in cancer. Oncogene 2007; 26:7499-507.

10. Rozenblatt-Rosen 0, Hughes CM, Nannepaga SJ, Shanmugam KS, Copeland TD, Guszczynski T, et al. The parafibromin tumor suppressor protein is part of a human Pafl complex. Mol Cell Biol 2005; 25:612-20.

11. Lin L, Czapiga M, Nini L, Zhang JH, Simonds WF. Nuclear localization of the parafibromin tumor suppressor protein implicated in the hyperparathyroidism-jaw tumor syndrome enhances its proapoptotic function. Mol Cancer Res 2007;5:183-93.

12. Mosimann C, Hausmann G, Basler K. Parafibromin/Hyrax activates Wnt/Wg target gene transcription by direct association with beta-catenin/Armadillo. Cell 2006;125:327-41.

13. Wang P, Bowl MR, Bender S, Peng J, Farber L, Chen J, et al. Parafibromin, a component of the human PAF complex, regulates growth factors and is required for embryonic development and survival in adult mice. Mol Cell Biol 2008;28:2930-40.

14. Zhang C, Kong D, Tan MH, Pappas DL, Jr., Wang PF, Chen J, et al. Parafibromin inhibits cancer cell growth and causes G1 phase arrest. Biochem Biophys Res Commun 2006;350:17-24.

15. Porzionato A, Macchi V, Barzon L, Masi G, Iacobone M, Parenti A, et al. Immunohi stochemical assessment of parafibromin in mouse and human tissues. $J$ Anat 2006;209:817-27.

16. Cetani F, Ambrogini E, Viacava P, Pardi E, Fanelli G, Naccarato AG, et al. Should parafibromin staining replace HRTP2 gene analysis as an additional tool for histologic diagnosis of parathyroid carcinoma?. Eur J Endocrinol 2007;156:547-54.

17. Gill AJ, Clarkson A, Gimm 0, Keil J, Dralle H, Howell VM, et al. Loss of nuclear expression of parafibromin distinguishes 
parathyroid carcinomas and hyperparathyroidism-jaw tumor (HPT-JT) syndromerelated adenomas from sporadic parathyroid adenomas and hyperplasias. Am J Surg Pathol 2006;30:1140-9.

18. Selvarajan S, Sii LH, Lee A, Yip G, Bay BH, Tan $\mathrm{MH}$, et al. Parafibromin expression in breast cancer: a novel marker for prognostication? J Clin Pathol 2008;61:64-7.

19. Tan MH, Morrison C, Wang P, Yang X, Haven CJ, Zhang $\mathrm{C}$, et al. Loss of parafibromin immunoreactivity is a distinguishing feature of parathyroid carcinoma. Clin Cancer Res 2004;10:6629-37.

20. Xia P, Wang W, Xu XY, Wang JP, Takano Y, Zheng HC. Parafibromin expression in lung normal tissue and carcinoma: its comparison with clinicopathological parameters of carcinoma. Histol Histopathol 2011;26:1039-47.

21. Zheng HC, Takahashi H, Li XH, Hara T, Masuda S, Guan YF, et al. Downregulated parafibromin expression is a promising marker for pathogenesis, invasion, metastasis and prognosis of gastric carcinomas.
Virchows Arch 2008;452:147-55.

22. Zheng HC, Wei ZL, Xu XY, Nie XC, Yang X, Takahashi H, et al. Parafibromin expression is an independent prognostic factor for colorectal carcinomas. Hum Pathol 2011;42:1089-102.

23. Wang PF, Tan MH, Zhang C, Morreau H, Teh BT. HRPT2, a tumor suppressor gene for hyperparathyroidism-jaw tumor syndrome. Horm Metab Res 2005;37:380-3.

24. Woodard GE, Lin L, Zhang JH, Agarwal SK, Marx SJ, Simonds WF. Parafibromin, product of the hyperparathyroidism-jaw tumor syndrome gene HRPT2, regulates cyclin D1/PRAD1 expression. Oncogene 2005; 24:1272-6.

25. Takahashi A, Tsutsumi R, Kikuchi I, Obuse C, Saito Y, Seidi A, et al. SHP2 tyrosine phosphatase converts parafibromin/Cdc73 from a tumor suppressor to an oncogenic driver. Mol Cell 2011;43:45-56.

26. Aldred MJ, Talacko AA, Savarirayan R, Murdolo V, Mills AE, Radden BG, et al. Dental findings in a family with hyperparathyroidism-jaw tumor syndrome and a novel HRPT2 gene mutation. Oral Surg Oral Med Oral Pathol Oral Radiol Endod 2006;101:212-8.

27. Pimenta FJ, Gontijo Silveira LF, Tavares GC, Silva AC, Perdigao PF, et al. HRPT2 gene alterations in ossifying fibroma of the jaws. Oral Oncol 2006;42:735-9.

28. Shattuck TM, Valimaki S, Obara T, Gaz RD, Clark OH, Shoback D, et al. Somatic and germ-line mutations of the HRPT2 gene in sporadic parathyroid carcinoma. N Engl J Med 2003;349:1722-9.

29. Zhao J, Yart A, Frigerio S, Perren A, Schraml P, Weisstanner C, et al. Sporadic human renal tumors display frequent allelic imbalances and novel mutations of the HRPT2 gene. Oncogene 2007;26:3440-9.

30. Tan MH, Wong CF, Tan HL, Yang XJ, Ditlev J, Matsuda D, et al. Genomic expression and single-nucleotide polymorphism profiling discriminates chromophobe renal cell carcinoma and oncocytoma, BMC Cancer 2010;10:196. 